\title{
A SZÜLETÉSI
}

KOHORSZVIZSGÁLATOK

PSZICHOLÓGIAI KÉRDÉSEI*

Lábadi Beatrix - Pohárnok Melinda

\section{ÖSSZEFOGLALÓ}

Az utóbbi évtizedekben az epidemiológiai fókuszú születési kohorszvizsgálatok mellett egyre nagyobb szerepet kapnak az összetett biopszichológiai-ökológiai szemléletű kutatások. Tanulmányunk kettős céllal született. Egyrészt bemutatunk egy olyan komplex értelmezési keretet, melyben a fejlődési változások több szinten, disztális és proximális tényezők függvényében értelmezhetők. Másrészt áttekintjük a kohorszvizsgálatokban hangsúlyos pszichológiai változók köré csoportosítható kérdéseket, amelyekkel kapcsolatban a nemzetközi születési kohorszvizsgálatok az elmúlt évtizedekben fontos új eredményeket hoztak. A pszichológiai fejlődés szemponjából két fő kutatási kérdést kiemelve elemezzük a kohorszkutatásokat: 1. hogyan jön létre az adaptív/maladaptív fejlődés a kockázati és védőtényezők mentén, és 2. milyen közvetlen és közvetett hatások alakítják a reziliens fejlődést. Tanulmányunkban a disztális változóktól a proximális felé haladva, kiemelt társadalmi és családi változókon keresztül mutatjuk be a nemzeti kohorszkutatásokat és az azok eredményeit kiegésztő kisebb volumenű longitudinális vizsgálatok tanulságait. Tárgyszavak: születési kohorsz-vizsgálat ; szerintem nem teszünk tárgyszavakat többes számba

Lábadi Beatrix, Pécsi Tudományegyetem, Pszichológia Intézet

E-mail: labadi.beatrix@pte.hu

Pohárnok Melinda, Pécsi Tudományegyetem, Pszichológia Intézet

E-mail: poharnok.melinda@pte.hu 


\section{A NEMZETKÖZI ÉS HAZAI SZÜLETÉSI KOHORSZVIZSGÁLATOK RÖVID ÁTTEKINTÉSE}

A gyermek pszichés fejlődését számos biológiai, interperszonális és környezeti tényező együttesen és folyamatosan alakítja. Az egymásra ható tényezők időbeli változását a longitudinális módszertanon alapuló kutatások tudják hitelesen feltárni. A keresztmetszeti eljárásokkal szemben a hosszmetszeti kutatások előnye, hogy az egyéni jellemzők változásán keresztül követik a fejlődési folyamatok alakulását, miközben feltárják a változásra ható tágabb szociális és környezeti kontextust is. A módszer természetéből adódóan a gyermek fejlődése ezáltal összetettebb és holisztikusabb perspektívából értelmezhető, és maga a gyermek és családja is úgy jelenik meg, mint aktív ágense a fejlődési változásnak. Ezért a longitudinális módszertant alkalmazó kutatások összetettebb és jobb ökológiai validitású fejlődési modelleket alapoznak meg, amelyek segítségével megismerhetjük, miként bontakozik ki és hogyan változik a gyermek veleszületett adottsága az életkörülmények, a családi és a társas kapcsolatok együttes hatására.

A longitudinális vizsgálatok speciális csoportját képező születési kohorszkutatások az azonos időszakban született gyermekek fejlődését követik megegyező globális (például történelmi, gazdasági) hatások mellett, megragadva a társadalmi, a családi és az egyéni változók közötti kapcsolatok jelentőségét a gyermek fejlődésében. E vizsgálatok sok esetben már a várandósság időszakában megkezdik az adatgyűjtést a család életkörülményeiről, a társas és családi hálózatról, az anya testi-lelki jóllétéről, a születendő gyermekre vonatkozó elvárásairól és érzelmeiről. A gyermek születését követően a kohorszvizsgálatok fókuszába a gyermeki fejlődés - úgy mint a testi-fizikai fejlődés, az érzelmi, társas és kognitív kompetenciák kibontakozása - és az azt befolyásoló dimenziók kerülnek, például az anya mentális egészsége vagy a család anyagi jóléte, illetve a tágabb környezeti hatások, társadalmi változások (Thornton, 2004).

Számos ország komoly hagyománnyal és tapasztalattal rendelkezik a születési kohorszvizsgálatok terén (összefoglalás a nemzeti születési kohorszvizsgálatokról: 1. táblázat), melyek jelentős része egészségügyi területen kutatja a felnövekvő gyermekek sajátosságait (összefoglaló ta- 
nulmány magyarul Blaskó, 2009). Ezek közül kiemelkedik a brit nemzeti vizsgálat, mely több nemzedéken keresztül kutatja a társadalmi, történelmi, demográfiai változások hatásait. Az első brit születési kohorszvizsgálat 1946-ban indult el (National Survey of Health and Development, NSHD), amelyet 1958-ban a National Child Development Study (NCDS), 1970-ben a British Cohort Study 1970 (BCS70) és a legújabb nemzedéket vizsgáló 2000-es Millennium Cohort Study (MCS) követett. Az első két vizsgálat még egészségügyi céllal született, a koraszülöttség és a csecsemőhalandóság állt a fókuszban. A későbbi vizsgálatok a gyermekek fizikai és mentális képességének fejlődését is nyomon követték. A legújabb Millennium Cohort adatgyűjtése már kiterjedt a kora gyermekkori fejlődés társadalmi és gazdasági háttértényezőire (szegénység, iskolai- és egészségügyi esélyegyenlőség), az anya és az apa mentális egészség változóira, nevelési, szülői attitűdjének, házastársi kapcsolatának vizsgálatára. Az előző kutatásokhoz képest nagyobb szerepet kaptak a gyermek olyan jellemzői is, mint a temperamentum és a kognitív fejlődés.

A születési kohorszkutatások egy része epidemiológiai jellegü vizsgálat, mely az egészségi állapotot befolyásoló változók közötti összefüggések megismerésére törekszik, azzal a céllal, hogy a feltárt ismeret a gyakorlatban hasznosíthatóvá váljon az életkörülmények és az egészségi állapot javítását szolgáló szociális és egészségügyi beavatkozásokkal. Ilyen kutatás például a kilencvenes években indult AVON Longitudinal Study of Parents and Children (ALSPAC), amely 14500 Bristol környékén élő család egészségügyi állapotát követi nyomon, hangsúlyt fektetve a genetikai háttérre, a fizikai fejlődésre, az általános egészségi állapotra és a betegségre való hajlamra. Az epidemiológiai fókuszú vizsgálatok mellett népszerüek a szélesebb társadalomtudományi kérdésekre is kiterjedő, interdiszciplináris, nagy mintás kohorszkutatások. Ilyen átfogó nemzeti kutatásokat (1. táblázat) találunk, a teljesség igénye nélkül, az Egyesült Királyságban (például Born in Bradford, BiB), az Egyesült Államokban (Early Childhood Longitudinal Study, ECLS), Írországban (Growing up in Ireland, GUI) Új-Zélandon (Growing Up in New Zealand, GUiNZ), Ausztráliában (Longitudinal Study of Australian Children, LSAC) és Franciaországban (French Longitudinal Study of Children, ELFE). 







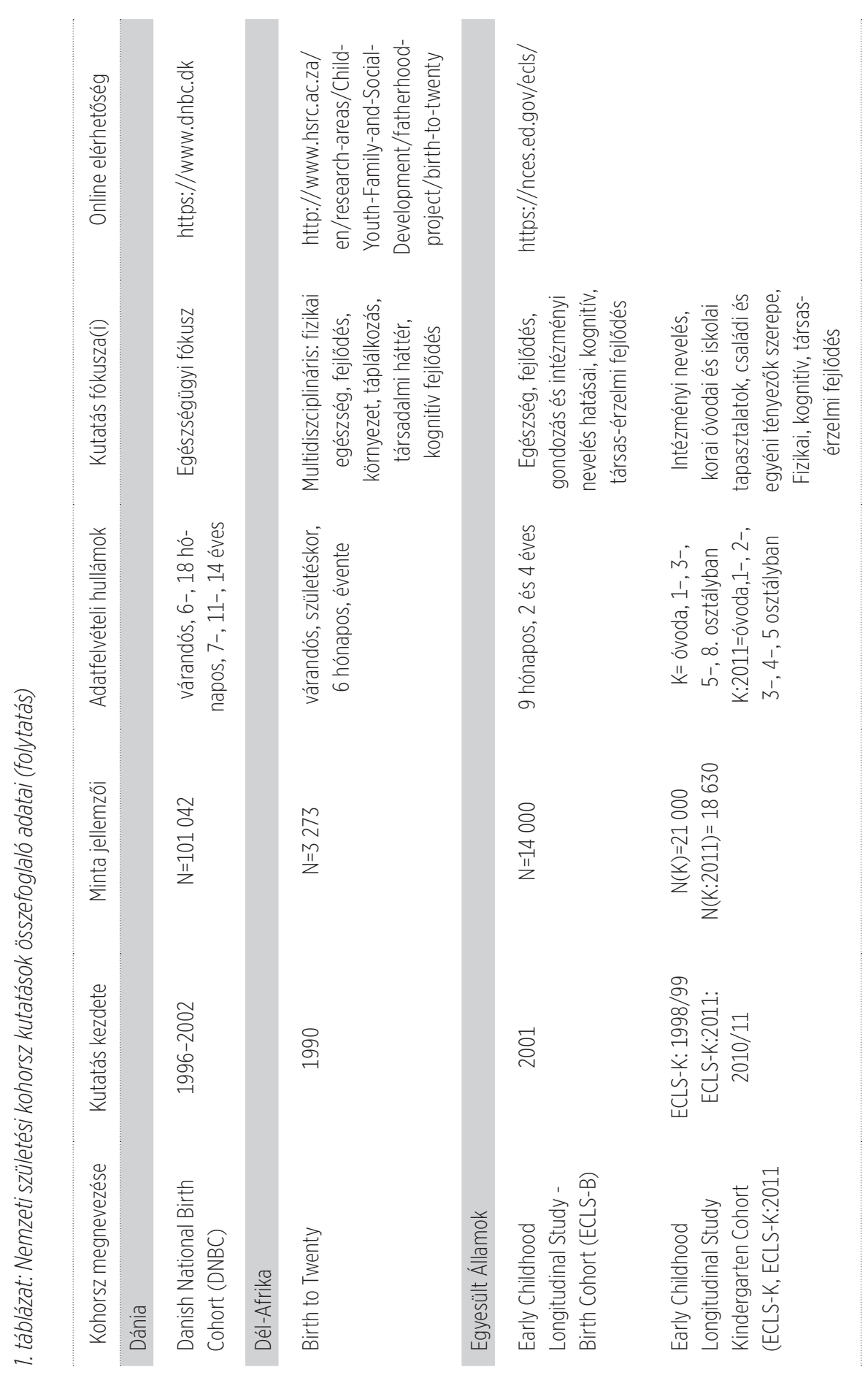














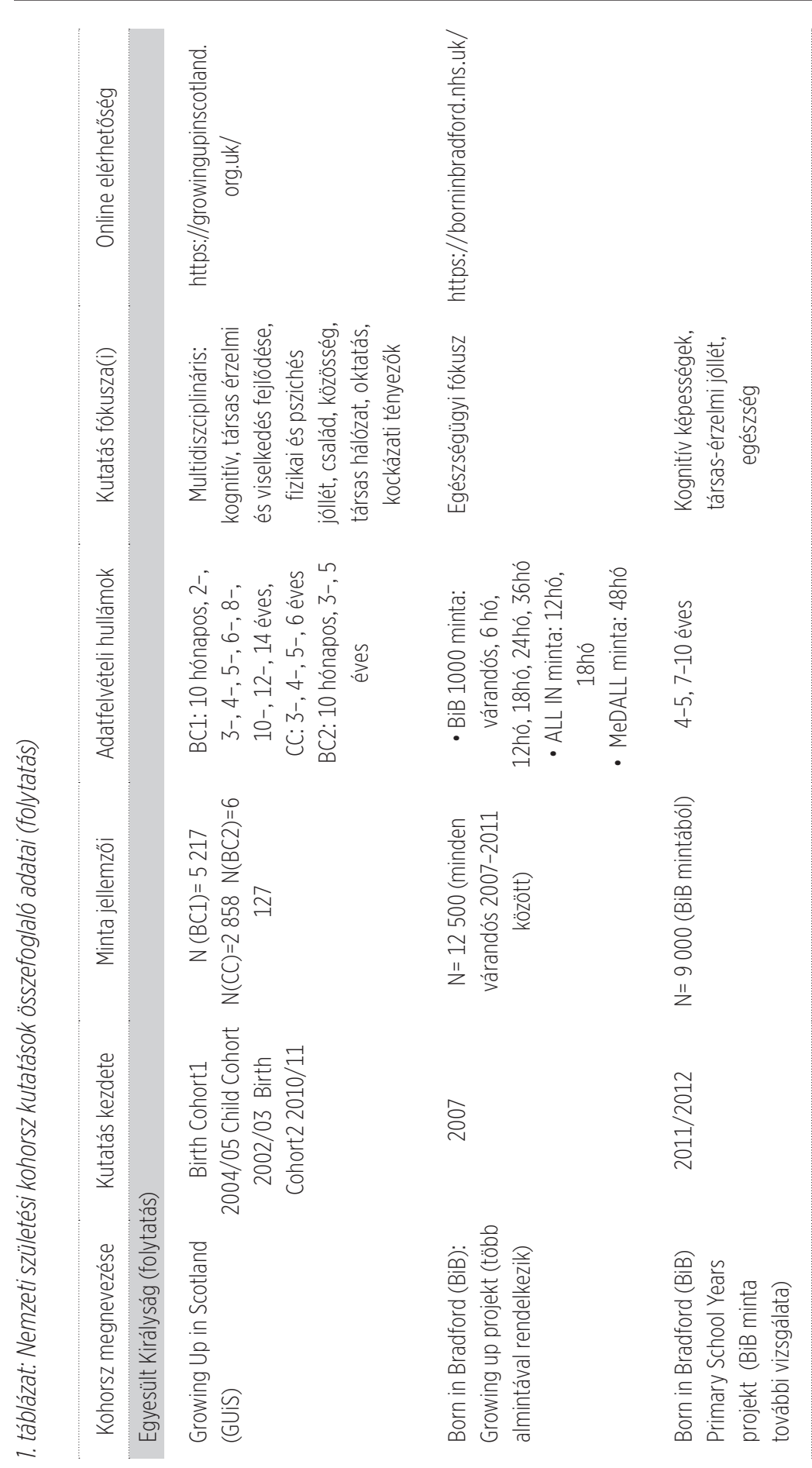




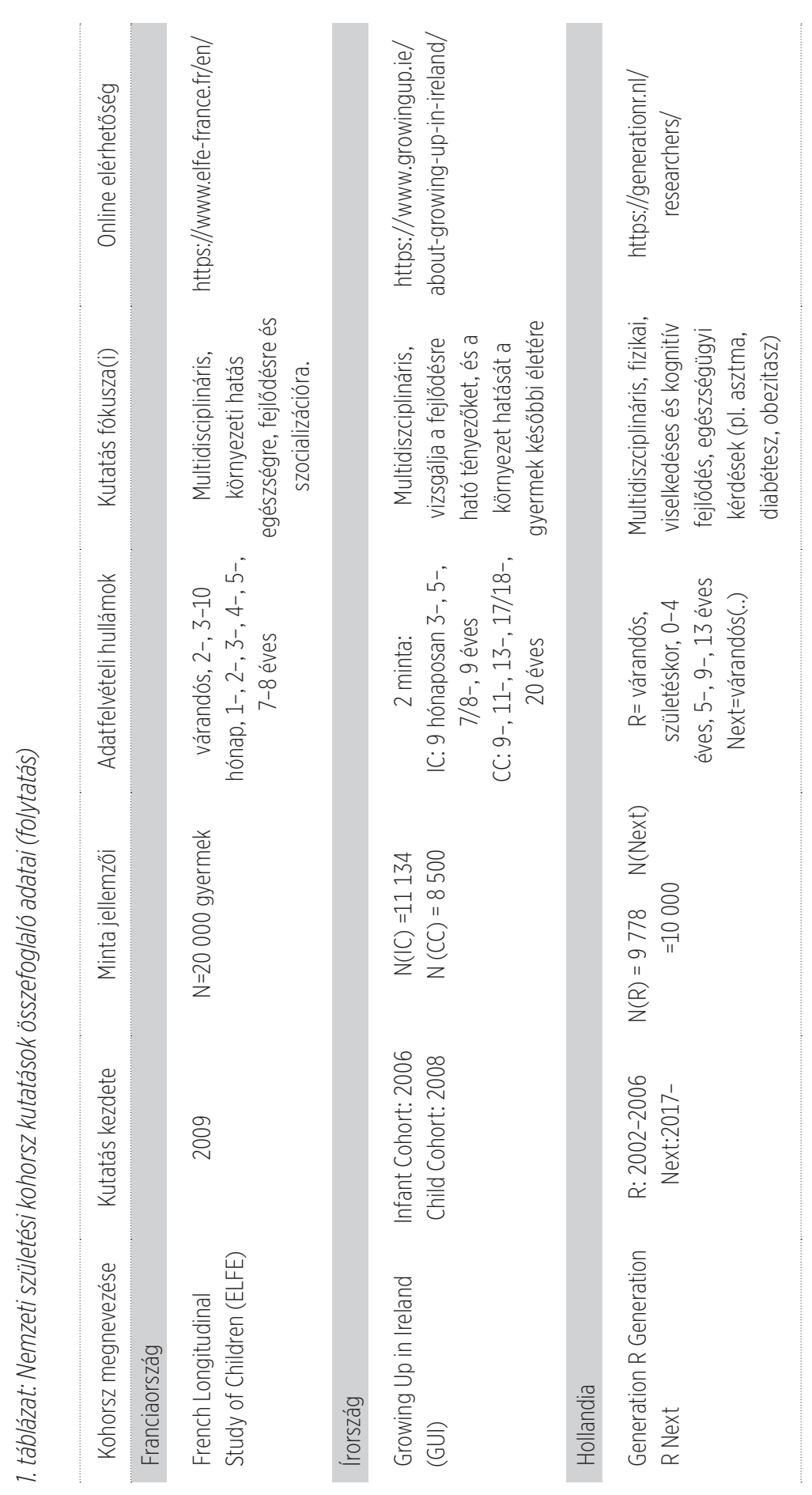




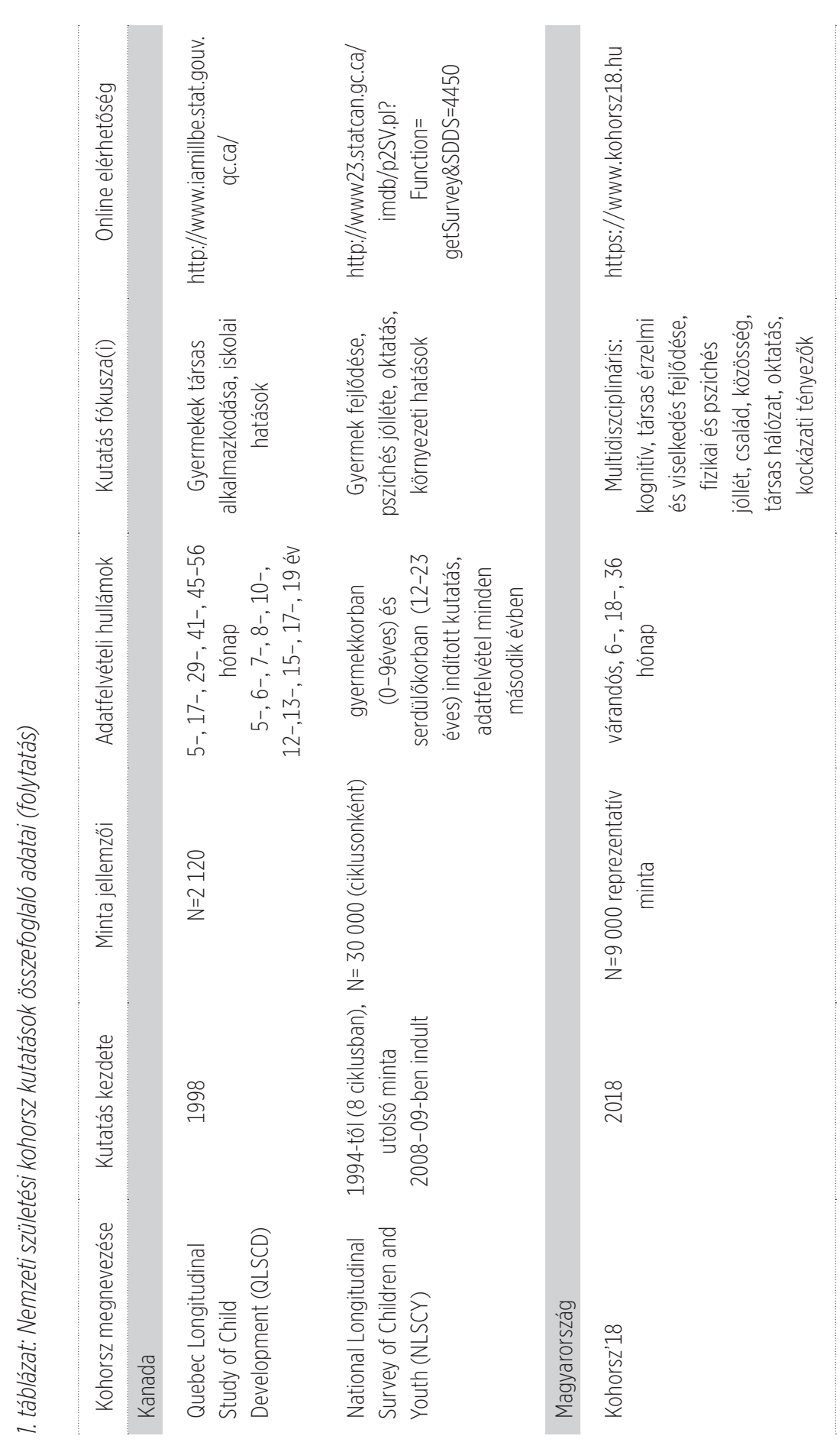




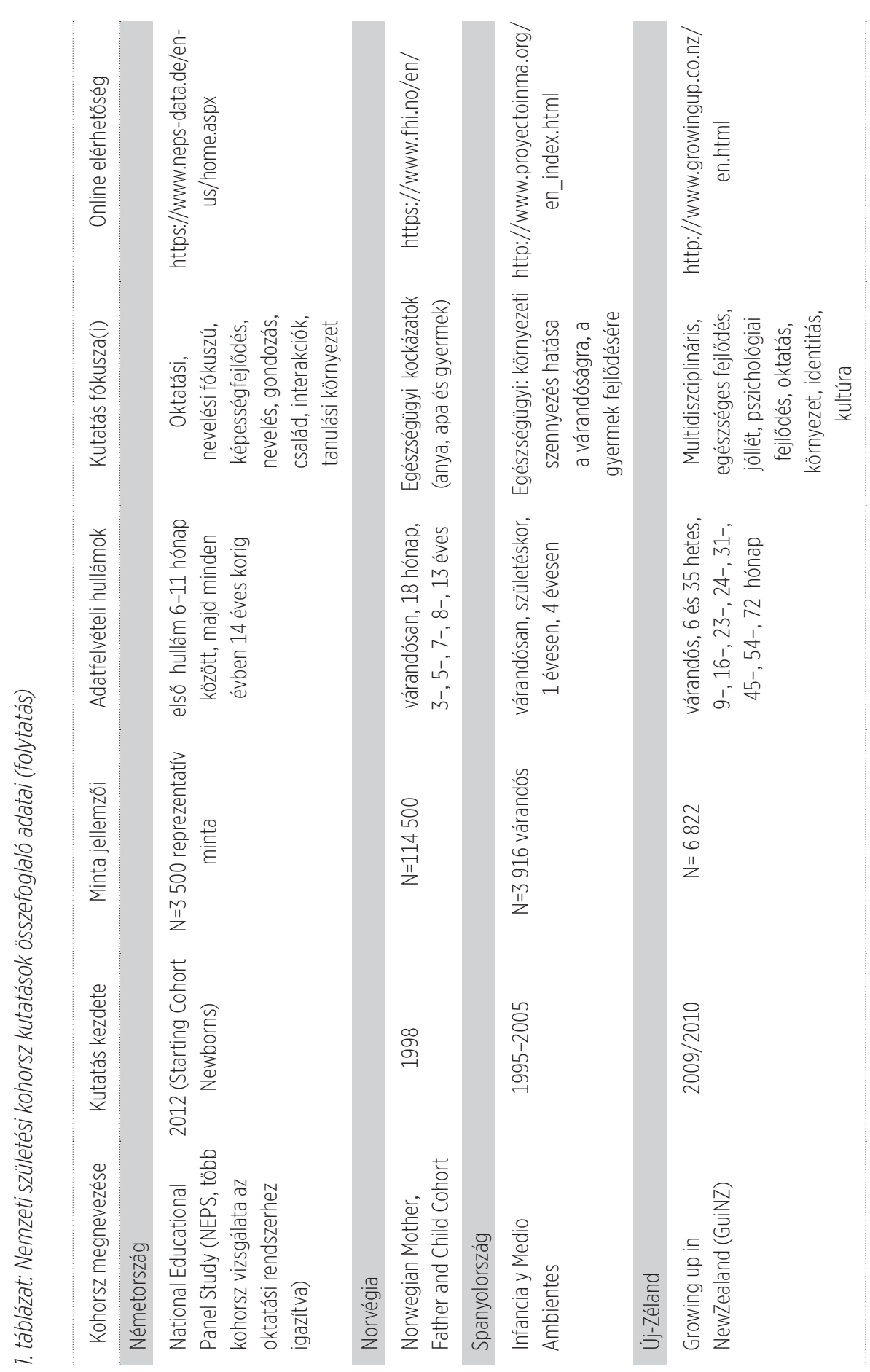


Magyarországon viszonylag kevés nagyobb volumenű longitudinális vizsgálat született az elmúlt néhány évtizedben (összefoglaló magyarul: Blaskó, 2009). A longitudinális vizsgálatok közül az országos longitudinális gyermeknövekedés vizsgálat emelkedik ki, amely alapvetően egészségügyi kutatási céllal született. A várandósság 20. hetétől (6300 fős mintával) egészen a gyermek 18 éves koráig (1800 fő) tartott az adatgyűjtés, amely a gyermek testi fejlődését és egészségi állapotát helyezte a kutatás homlokterébe, kiegészítve a gyermeki jólétre vonatkozó kérdésekkel (Gárdos, 1990, Joubert és Gárdos, 1991, Joubert, 2006). A másik jelentős kutatás, a budapesti longitudinális vizsgálat a gyermeki pszichológiai fejlődés nyomon követésére született. Az első vizsgálat 1982-ben a gyermekek három hónapos adatfelvételével kezdődött, amelyet még öt adatgyűjtési időpont követett: kétéves, nagycsoportos óvodás, 2. osztályos, 6. osztályos és fiatal felnőttkorban (22-23 évesen). A minta 443 fő részvételével kizárólag Budapesten született gyermekekre vonatkozott. A vizsgálat kiterjedt a pszichológiai változókra (például intelligencia), a szülői kapcsolatokra, a nevelési kérdésekre, a család szocioökonómiai státuszára és a deviáns magatartásformák előfordulására (Ranschburg és Horváth, 1985, Ranschburg et al., 1995, Bass, 2007). A harmadik jelentős kutatás, a budapesti családvizsgálat (Gervai, 2005) a korai fejlődés és a családi tényezők pszichológiai aspektusainak longitudinális vizsgálatát tűzte ki célul. A kutatás az első gyermekét nevelő 103 családban követte nyomon a korai szülő-gyermek kapcsolatot és az érzelmi-szociális fejlődést a születéstől a gyermekek hatéves koráig. Hazánkban születési kohorszvizsgálatra a 2018-ban elindult Kohorsz’ 18 megnevezésű kutatás előtt nem volt példa. A KSH Népességtudományi Kutatóintézete által indított reprezentatív mintán végzett kutatás mintegy 8500, 2018/19-ben született gyermek felnövekedését követi nyomon a várandósság harmadik trimeszterétől. A vizsgálat kérdései többek között kiterjednek a gyermekvállalási és a gyermeknevelési körülményekre, a születendő gyermekek társas-érzelmi és kognitív fejlődését meghatározó szülői, családi és társadalmi sajátosságokra (Veroszta, 2018).

Összefoglaló tanulmányunk első felében bemutatjuk a születési kohorszkutatások pszichológiai változóinak értelmezéséhez jól illeszkedő biopszichológiai ökológiai modellt, amely a fejlődést a gyermek szükebb és tágabb környezetével folytatott tranzakciós folyamatokon keresztül ragadja meg. Ezen elméleti kereten belül az adaptív/maladaptív fejlődés dinamikus folyamatát a rizikó- és a protektív tényezők, valamint a fejlődési kimeneti változók közötti kapcsolatok elemzési lehetőségeit felhasználva mutatjuk be. A tanulmány második felében áttekintjük a születési kohorszkutatásokban megjelenő pszichológiai változókat és kérdéseket, a kognitív, társas-érzelmi fejlődés kibontakozását és a pszichés 
egészséget befolyásoló tényezőket a disztálisoktól a proximálisak felé haladva. A pszichológiai változók szerepének tisztázásához longitudinális kutatások eredményeit használjuk fel, törekedve a nagyobb reprezentatív mintán alapuló nemzeti születési kohorszvizsgálatok előtérbe helyezésére, ugyanakkor idézünk kisebb volumenü kutatásokat is, ha eredményeik pontosítják és többletinformációval gazdagítják az általánosabb összefüggéseket.

\section{A PSZICHOLÓGIAI FEJLÖDÉS KIBONTKOZÁSA A RIZIKÓ- ÉS PROTEKTÍV FAKTOROK MENTÉN}

A longitudinális vizsgálatok sajátossága, hogy a gyermek fejlődését tágabb ökológiai keretben a bioszociális környezet (Bronfenbrenner and Ceci, 1994) részeként értelmezik. A gyermek várható fejlődési kimenetét (társas, érzelmi és kognitív kompetenciáját) az egyéni jellemzői (temperamentum, fizikai és egészségi állapot), a szülői tényezők (anya/apa pszichés-mentális egészsége, társas, érzelmi és kognitív kompetenciája, szülői/nevelői attitűdje és nevelési gyakorlata), a szülők közötti kapcsolat (a párkapcsolat minősége, konfliktusok gyakorisága), a gyermek és az anya közötti kapcsolat minősége (biztonság, melegség, válaszkészség), valamint a gyermek és családja mikrokörnyezeti (családi és közvetlen környezeti hatások, feltételek) és makrokörnyezeti (társadalmi, kulturális és gazdasági) jellemzői együttesen határozzák meg. A több szinten megjelenő hatásokat, interakciókat a gyermek életkori szakaszaihoz igazodó fejlődési teljesítmények elérése mentén és a pszichés jóllétének (mentális egészség) vizsgálatán keresztül tudjuk megragadni. A gyermek fejlődése mindenkori biológiai adottságainak és a környezet olyan jellemzőinek függvényében alakul, amelyek támogatják vagy nehezítik a gyermekben rejlő adottságok kibontakozását.

A fejlődési lehetőségek kibontakozását hátráltató rizikótényezők növelik a gyermek fejlődési sérülékenységét. Ezek egy része olyan közeli (proximális) biológiai és pszichoszociális faktor, mint a szülők pszichiátriai problémái (például szülői szerhasználat, anyai depresszió, szorongás), házastársi konfliktusok, válás, negatív életesemények (például veszteségélmények, a szülő halála), elhanyagoló vagy bántalmazó bánásmód (Rutter et al., 1997). Másrészt olyan távoli (disztális) környezeti kockázati tényezők, melyek hosszú távon, sokszor későbbi életkorban manifesztálódó problémák megjelenésével nehezítik az egészséges fejlődés kibontakozását; ilyen tényező például a szegénység, a szülők alacsony iskolázottsága, az egyszülős vagy sokgenerációs család szűkös erőforrásokkal 
(Gerard and Buehler, 2004), vagy a rossz lakókörnyezet (összefoglaló tanulmány a rizikó- és protektív tényezők hatásáról Danis és Kalmár, 2011).

A rizikófaktorok jelenléte tehát növeli a valószínüségét, hogy a gyermek kognitív kompetenciája nem éri el az adottságai alapján elvárható optimális szintet, és ezzel együtt több viselkedéses alkalmazkodási problémával kell megküzdenie élete során. Viszont nem egyszerüen egy-egy rizikófaktor jelenléte az oka a fejlődési nehézség megjelenésének. Ahogyan a fejlődési elméletekben megjelenő tranzakciós (Sameroff and Chandler, 1975) és interakciós (Bronfenbrenner and Ceci, 1994) folyamatokat előtérbe helyező modellek rámutattak, egy fejlődési eredmény egyszerre több közvetlen és közvetett, moderáló változó hatására reflektálva manifesztálódik. Ennek következtében az 1980-as évektől megjelent longitudinális kutatások már a kockázati tényezők kumulatív (összeadódó) és halmozódó hatását vizsgálták. Egy ilyen magyarázó modellben például az anyai mentális problémák többnyire nem önmagukban állnak, hanem egymásba ágyazódó tényezők (például alacsony családi jövedelem és alacsony szülői iskolai végzettség, kaotikus családi viszonyok és zavaros vagy fenyegető környék) egyik elemeként. Amennyiben ezek a tényezők együtt járnak, hatásuk többszöröződik, és a gyermeki fejlődési kimenetek kedvezőtlenebb prognózisúak lesznek, mintha csak önmagukban hatnának (Sameroff et al., 1987). Például Sameroff és munkatársai (Sameroff and Seifer, 1983) a Rochester Longitudinal Study-ban igazolták, hogy legalább három-négy kedvezőtlen körülmény együttes előfordulása sokkal jobban valószínüsíti a gyermek intellektuális színvonalának csökkenését, mintha csak egy vagy két kockázati tényező lenne jelen a gyermek életében.

A kockázati tényezők jelenléte és halmozódása hosszú távon befolyásolja a felnövekvő gyermek jóllétét, az iskolai, majd munkahelyi teljesítményét, végső soron pedig az egészségi állapotát és a szociális kapcsolatait. A kockázati becslések ellenére ugyanakkor a nehéz körülmények nem determináló hatásúak a felnőtté válás folyamatában, mint ahogy erre a tényre a nyolcvanas évektől ismert ún. rezilienciakutatások rámutattak (Rutter, 1989, Luthar and Zelazo, 2003, Masten, 2007). A gyermek egyéni és társas védőfaktorai képesek módosítani vagy megakadályozni, hogy a nehéz szociális és/vagy környezeti tényezők hatására a gyermek felnövekedése maladaptív irányba fejlődjön.

A protektív tényezők egyéni, családi és tágabb társas környezeti szinten moderálják a gyermekkori nehézségek, például a rossz bánásmód következményeit. A fejlődés védőmechanizmusait vizsgáló tanulmányok a reziliencia tradicionális gondolkodásmódja szerint értékelik a gyermek fejlődését, vagyis a „jobb kimenet, mint a fennálló körülményekhez mérten várhatnánk” logika szerint értelmezik az eredményeket. Miközben azonosítják a védőmechanizmusok 
három forrását: a gyermek tulajdonságait (személyes erőforrását, úgy mint temperamentum, tanulási képességek, önértékelés, adaptív készségek), a családi jellemzőket (kötődés, szülői bánásmód, szülő-gyermek kapcsolat) és a szociális környezetet (óvoda, iskola, szomszédság, barátok). Jó példa a reziliens fejlődés tanulmányozására a svéd születési kohorszvizsgálat (Agnafors et al., 2017), ahol összetett statisztikai módszer segítségével vizsgálják a kockázati tényezők és a reziliencia közötti összefüggéseket. A modell a gyermekek születésétől a serdülőkorig vizsgálja a kockázati tényezők (anyai depresszió, traumatikus életesemények, pszichoszociális kockázati tényezők) és a feltételezett rezilienciafaktorok (genetikai adottság, temperamentum, szociális funkcionálás és anyai koherenciaérzés) interakcióját. Az eredmények alátámasztják, hogy a hároméves korban rendelkezésre álló rezilienciaforrások meghatározzák a preadoleszcens korban mérhető fejlődési kimenetet. Továbbá az egyéni és a családi protektív erőforrások interakciója együtt alakítja a gyermek pszichés egészségét. A rossz bánásmód és a reziliens kimenet közötti kapcsolatot elemző szisztematikus metatanulmány (Meng et al., 2018) 85 korábban publikált hossz- és keresztmetszeti vizsgálat eredményeit felhasználva úgy összegez, hogy a reziliens jellemzők jelenléte jobb életkilátást eredményez, csökkenti a pszichopatológiai állapot megjelenésének kockázatát, a traumatizáció valószínüségét, növeli az észlelt pszichológiai jóllét szintjét és az adaptív készségek fejlődését.

A rezilienciaforrások hatása ugyanakkor nem minden feltétel mellett egyforma. A reziliencia cél- és kontextusfüggő működéséről azok a kutatások nyújtanak még részletgazdagabb információkat, amelyek valamely globális rizikótényező egyes aspektusait szeparáltan vizsgálják. A rossz bánásmód különböző típusainak - fizikai vagy szexuális bántalmazás, érzelmi bántalmazás/elhanyagolás - hatásaival szembeni rezilienciát vizsgálta egy az ALSPAC adataira épülő friss kutatás (Khambati et al., 2018). Eredményeik azt látszanak igazolni, hogy a kora gyermekkori érzelmi és fizikai elhanyagolás hatását hasonló faktorok, de más erővel és más irányban befolyásolják. Az érzelmi elhanyagolásnak a serdülőkori mentális jóllétre, önértékelésre és iskolai teljesítményre való negatív hatásával szemben a 6 és 9 éves kor között mutatott magasabb intelligencia, jobb kommunikációs készségek, erősebb belső kontroll, az iskolán kívüli aktivitásokban való intenzívebb részvétel és az iskolához kapcsolódó elégedettségérzés protektív faktorként hat. A fizikai bántalmazás esetében ugyanezen protektív tényezők bizonyultak valamelyest hatékonynak, de kizárólag az iskolai teljesítmény tekintetében, tehát a fizikai bántalmazásnak a mentális jóllétre és az önértékelésre kifejtett romboló hatása tekintetében nem találtak protektív tényezőt. Mindebből arra következtethetünk, hogy ha már serdülőkori kimenetet vizsgálunk, akkor a korai, gyermeki és családi tényezők interakciója mel- 
lett egyre nagyobb hangsúlyt kapnak a gyermek és intézményi környezete (iskola és szolgáltatások) közötti interakciók a reziliencia alakulásában. Ungar (2015) felveti annak lehetőségét is, hogy minél jelentősebb a társadalmi hátrány, annál inkább megnő a környezeti, például az intézményi faktorok szerepe a protektív tényezők körében. A kutatás ugyanakkor két további megfontolásra is felhívja a figyelmet. Egyrészt a pszichológiai fejlődés szempontjából nem beszélhetünk általános, csak kimenet- és kontextusfüggő rezilienciaforrásokról. Hiszen a rossz bánásmód eltérő típusainak hatását más tényezők és más kimenetre hatva moderálják. Másrészt, mivel a korábbi eredményeket (például DuMont et al., 2007) megerősitve itt is azt találták, hogy a bántalmazással, elhanyagolással szemben reziliens gyermekek aránya megközelítőleg ugyanakkora, mint az elvárható maladaptív kimenetet mutató gyermekek aránya, így a longitudinális prospektív vizsgálatokban ugyanolyan módon érvényes a sérülékenység és a rizikótényezők vizsgálata, mint a pszichés ellenállóképesség (reziliencia) és a stresszorokkal szembeni védettség vizsgálata.

\section{A SZÜLETÉSI KOHORSZKUTATÁSOK KIEMELT KUTATÁSI KÉRDÉSEI}

\section{A társadalmi tényezők hatása - szegénység, szocioökönómiai státusz, etnikum}

A fejlődéselméletek szociális irányultságú megközelítése szerint a gyermek és családja része a mindenkori kulturális, társadalmi, történelmi rendszernek, minek következtében az adott társadalmi és kulturális csoporthoz való tartozás, valamint az arról való társadalmi közgondolkodás, attitűdök, normák hatással vannak a család és a gyermek életére. A születési kohorszkutatások már a kezdetektől jelentős erőfeszítéseket tettek, hogy feltárják, milyen kockázati szerepet töltenek be a tágabb makrotársadalmi tényezők, úgy mint a család társadalmi és gazdasági helyzete, a kisebbségi etnikumhoz vagy szubkultúrához való tartozás a gyermek testi és lelki fejlődésében. Már az első brit születési kohorszkutatás (NCDS) is figyelmet fordított a társadalmi státusz és az egészségügyi állapot, a viselkedésben megmutatkozó problémák, valamint az iskolai eredményesség közötti kapcsolatra. Az eredmények rámutattak, hogy a szülők alacsony szocioökonómiai státusza csökkenti a gyermek iskolai teljesítményét és korlátozza hosszú távú továbbtanulási lehetőségeit még akkor is, ha a gyermek jó kognitív képességekkel rendelkezik (Douglas et al., 1968). 
Az újabb születési kohorszvizsgálatok törekszenek a társadalmi kockázati tényezőknek (SES, szegénység, etnikum, szubkultúra) a gyermeki fejlődésben betöltött szerepét a közvetítő és a moderáló faktorokkal együtt vizsgálni. Schoon és munkatársai (2002) két, az Egyesült Királyságban végzett, korábban már említett születési kohorszvizsgálat (NCDS, MCS) adatait vizsgálva arra a következtetésre jutottak, hogy a születéskori társadalmi osztály és a felnőttkori foglalkozási státusz közti pozitív kapcsolatot nagyrészt a gyermekkori jövedelmi tényezők közvetítik. Miközben arra is rámutatnak, hogy a társadalmi osztály, a kultúra és az etnikum hatását a közvetlen környezeti tényezőkön túl az olyan proximális változók kötik össze a hosszú távú alkalmazkodási nehézségekkel, mint a gyermekek által megélt fiziológiai és pszichológia stressz emelkedett szintje és a korai önszabályozási készségek zavart fejlődése (Evans et al., 2013).

Kisebb volumenü, de finomabb elemzést lehetővé tevő követéses vizsgálatok (például Blair et al., 2011) bizonyították, hogy a makrotársadalmi tényezők közvetítő változókon keresztül fejtik ki hatásukat. Például a súlyos anyagi és lakhatási nehézségek közvetlen befolyással bírnak a csecsemők és a kisgyermekek stressz-szabályozó rendszerére, ami közvetíti a diszfunkcionális működést, és felelőssé tehető a gyermekek későbbi érzelmi és kognitív szabályozási folyamataiban mutatkozó zavarokért (Blair and Raver, 2016). Hasonló eredményekre jutottak a viselkedéses problémák és a szegénység kapcsolatáról az ausztrál kohorszvizsgálatban is (LSAC; Warren, 2017), ahol azt is megállapították, hogy az összefüggést nagyrészt az alacsonyabb szülői befektetés, a rosszabb szülői mentális egészség és a negatív szülői nevelési stílusok közvetítik.

Valószínűsithető, hogy a hagyományosan kockázati tényezőként számon tartott makrotársadalmi változóknak (rassz/etnikum, szociökonómiai státusz, társadalmi osztály) a gyermeki fejlődésre kifejtett hatásai is főként a kumulatív rizikó mentén hatnak. Az etnikai hovatartozás kapcsán a GUiNZ első eredményei ezt a feltevést támasztják alá. A kisebbségi maori vagy csendes-óceáni népcsoportokhoz való tartozás Új-Zélandon nem önmagában jelent fejlődési kockázatot, hanem azon társas-társadalmi és közvetlen környezeti tényezők mentén (például túlzsúfolt otthonok, elszigetelt vidék, az anya alacsony iskolai végzettsége), amelyek a kisebbségi lét járulékos jellemzői (Morton et al., 2014). Az új-zélandi kohorszkutatás (GUiNZ; Morton et al., 2015) erre utaló eredményei szerint a közepes szintű családi és gazdasági-társadalmi rizikót megtapasztaló gyerekek kétszer nagyobb eséllyel mutattak korai viselkedéses problémákra utaló jeleket, mint az alacsony rizikójú csoport. A magas rizikójú csoportban ugyanakkor a hétszeresére nőtt az esélye annak, hogy kétévesen a gyerekek súlyosabb viselkedési alkalmazkodási nehézségeket mutassanak. A fejlődési 
kockázatot valószínüsítő tényezők fennállásának időbeli stabilitása is alakítja a gyermek fejlődési pályáját. Az időben hosszan fennmaradó magas kockázat sérülékennyé teszi a gyermeket, és növeli a későbbi viselkedéses problémák előfordulásának esélyét. Ezzel szemben az idővel növekvő számú vagy rövidebb ideig tartó kockázati tényezőkhöz a gyermekek könnyebben adaptálódnak.

\section{A társadalmi tényezők hatása - intézményes nevelés}

Az intézményes nevelés mint környezeti tényező sajátos, kettős szerepet tölt be a fejlődés alakitásában. Ha a hatásait tanulmányozzuk, iskolapéldájává válik azoknak a változóknak, amelyeknek protektív vagy rizikótényezőként betöltött szerepe nem egyértelműen meghatározható. Hiszen csecsemő- és kisgyermekkorban kockázati tényezőként is tekinthető az anyától való korai szeparáció, az alacsonyabb gondozói válaszkészség és támogatás (Dowsett et al., 2008) és a kortárscsoportokban átélt magasabb stressz (Vermeer and van IJzendoorn, 2006) okán. Ugyanakkor - főleg a formális oktatást megelőző években és a társadalmilag deprivált környezetben - lehetőséget adhat fejlődési lemaradások ledolgozására, ilyen értelemben védőfaktorként is müködhet.

Az angolszász területeken, ahol az anyák többsége a gyermek életének első éveiben visszatér a munkába, és a kisgyermekkori intézményes ellátás jóval diverzebb, mint hazánkban, az élet első négy évében megélt gondozási és nevelési tapasztalatoknak az iskolai teljesitményre kifejtett hatása intenzíven vizsgált téma. Két születési kohorszvizsgálat - az Egyesült Államokban (ECLS-B) és Ausztráliában (LSAC-B) - adatait elemző vizsgálatok (Coley et al., 2015; Coley et al., 2016) arra az eredményre jutottak, hogy a 3-5 éves kor közötti intézményes nevelés, legyen az akár családi bölcsőde vagy intézményi bölcsőde rendszerü, teljes napos vagy részleges ellátás, összességében csekély mértékben, de fejlesztő hatással bír a gyermekek ötéves korban mért tanulási készségeire (korai számolás, az írás-olvasás képessége). Ugyanakkor ha a korai formális intézményi ellátást vetették össze a rokonok vagy a gyermekgondozók általi otthoni ellátással, az előbbi jobban előmozdította a kognitív készségek fejlődését, mint az utóbbi. Ugyanis azok, akik kora és kisgyermekkorban formális bölcsődei, óvodai ellátásban vettek részt, jobb iskolai teljesítményt (jobb nyelvi és olvasási készségeket) mutattak a nem formális gondoskodásban részesülőkhöz képest. Ugyanakkor érdekes megfigyelés, hogy a gyermekek agresszív, diszruptív viselkedése és a tanulást akadályozó viselkedési problémák (figyelmetlenség, a kitartás hiánya a feladatmegoldásban) szintén pozitív módon kapcsolódott az 
intézményes ellátáshoz. Ez a hatás annál fokozottabb volt, minél korábban kezdte a bölcsődét a gyermek és minél több időt töltött az intézményben egy nap (Coley et al., 2013). Összességében elmondható, hogy a csecsemőkori és a kisgyerekkori nem szülői gondoskodás időzítésének, típusának és mértékének változói additív módon hatva fejtik ki hatásukat a gyermekek sikeres viselkedéses alkalmazkodására és a korai kognitív teljesítményükre. Mindezek mellett megjegyzendő, hogy az intézményválasztást a család anyagi, társadalmi helyzete is befolyásolja, így ezek a háttértényezők is módosítják az intézményes gondoskodás és nevelés hatását.

\section{A családi tényezők hatása - a családi struktúra és a családi stabilitás}

A családi atmoszféra és a családi struktúra szerepe ma már vitathatatlan a gyermek érzelmi és társas fejlődését illetően. Számos Iongitudinális kutatás igazolta a családi stabilitás, a családi struktúra, valamint a házastársi kapcsolat szerepét a gyermekek fejlődési pályájának alakulásában (Lacey et al., 2014, összefoglaló: Hadfield et al., 2018). Az elmúlt évtizedekben a családi intézményrendszerben bekövetkező változások követése és hatásának feltérképezése komoly kihívást jelentett a longitudinális kutatások számára. A kutatási kérdések közül kiemelkedik a házastársi kapcsolat (házasságban vagy élettársi kapcsolatban élő, gyermeket egyedül nevelő szülők) és a családban bekövetkező változások (strukturális: válás, mozaikcsalád, és a változás bekövetkezésének ideje) következményeinek megismerése. McLanahan és Sandefur (1994) klasszikus tanulmányukban először foglalták össze az amerikai nemzeti longitudinális felmérések eredményeit a modern családi változások tükrében, kiemelve a szülők közötti kapcsolat és a családi struktúra jellegét. Eszerint azokra a gyermekekre, akik kétszülős családban születnek, kevésbé jellemző az iskolai kimaradás, a serdülőkori terhesség és a fiatal felnőttkori munkanélküliség, mint az egyszülős háztartásban felnövőkre. Ugyanakkor arra is rámutattak, hogy a kétszülős családi modell önmagában még nem jelent automatikus védettséget, hiszen a házassági együttélés alternatívájaként ismert élettársi kapcsolat az együtt élő két szülő ellenére rizikónak számít. Jelentőségét mi sem mutatja jobban, mint hogy a szakirodalomban külön kifejezéssel illetik, törékeny család (fragile family) néven, ami arra utal, hogy az ilyen családban a gyermekek nagyobb valószínüséggel szembesülnek családi instabilitással, kevesebb szülői erőforrással és emelkedett stresszszinttel, összehasonlítva a házastársi kapcsolatban élő szülők gyermekeivel (Kalil and 
Ryan, 2010). Ezt támasztja alá a legújabb brit kohorszkutatás (MCS) is (Fomby, 2011), amely szerint a stabil házassági kapcsolatban élő párok gyermekeinél alacsonyabb a kockázata a fejlődési nehézségek kialakulásának, például kevesebb externalizáló és internalizáló viselkedési probléma figyelhető meg ötéves korban. Miközben a legjelentősebb gondok olyan családokban jelentkeznek, ahol bár a szülők elváltak, mégis egy háztartásban élnek, illetve a gyermeküket egyedül nevelő nők esetében. Ezeknél a gyermekeknél háromszor nagyobb a valószínűsége a viselkedési problémák kialakulásának, mint azokban a családokban, ahol a szülők házasságban élnek. Ugyanakkor fontos megjegyezni, hogy a gyermeküket egyedül nevelő nők esetében, ha figyelembe vesszük a család jövedelmét és az anya pszichés állapotát (például depresszív tünetek), akkor önmagában a családi állapot hatása lecsökken, ami arra utal, hogy nem kizárólag az egyszülős nevelés a kockázati tényező, hanem az azzal járó nehézségek. Általában elmondható, hogy a gyermeküket az édesapával nevelő nők jobb mentális egészségnek örvendenek, mint az egyedülálló anyák, akik számos nehézséggel küzdenek meg társas támasz nélkül, ezért nagyobb valószínűséggel élnek pszichés problémákkal (depresszió, szorongás), aminek következtében a szülői bevonódásuk is korlátozottabb lehet, és ez hosszú távon meghatározhatja a gyermek pszichológiai és érzelmi jóllétét.

A viselkedéses és alkalmazkodási zavarok kialakulásának másik kiemelt kockázati tényezője a családi struktúrában bekövetkező változás és a családi stabilitás hiánya, ami fokozottan jellemző az elvált és az új partnerükkel újraházasodó szülők családjaira. A családi stabilitás jelentős mértékben járul hozzá a gyermek és szülei testi és lelki jóllétéhez, ezért protektív tényezőként tartjuk számon. Miközben a stabilitás hosszú távú hiánya veszélyezteti a gyermek pszichológiai és társas funkcionálását, növeli a negatív fejlődési kimenetek megjelenésének valószínűségét a társas-érzelmi fejlődés területén (Lee and McLanahan, 2015), az iskolai teljesítményben és a kognitív képességekben (Sun and Li, 2014), valamint a fizikai egészségi állapotban (Bzostek and Beck, 2011). Az instabilitás közvetítő mechanizmusaként, hasonlóan, mint a hátrányos társadalmi-gazdasági helyzet esetén, a családban megjelenő emelkedett stresszállapotot nevezi meg a legtöbb magyarázó elmélet (társas stressz elmélet, George, 1993, Osborne and McLanahan, 2007, összefoglaló tanulmány: Hadfield et al., 2018). A családi struktúrában bekövetkező változás már önmagában stresszkeltő tényező, miközben további nehezen kezelhető következményekkel is együtt járhat, ami a családi életben bekövetkezett bizonytalanság negatív hatását tovább fokozza (Fomby and Cherlin, 2007). A családi átmeneti állapot gyakori járulékos következménye az anyagi források, a szülői érzelmi erőforrások és a gyermekekkel töltött idő csök- 
kenése (Osborne and McLanahan, 2007), a lakhatás bizonytalansága, valamint a változás a társas kapcsolatokban (például kevesebb társas támasz). A negatív következmények halmozódása az alacsony jövedelmü, kisebbségi népcsoporthoz tartozó családokban még fokozottabb, ugyanis nekik már a családi változás előtt is jelentős szociális és gazdasági hátránnyal kellett megküzdeniük (Brown et al., 2016). Ugyanakkor fontos megjegyezni, hogy nem minden tanulmány talált egyértelmű kapcsolatot a családi változás és a gyermeki fejlődés között (Hadfield et al., 2018, szisztematikus metaelemzés). Ennek feltehetően az az oka, hogy bár a családi változás mindig stresszel teli esemény a gyermek életében, a tanulmányok kevés figyelmet fordítanak a protektív tényezők jelenlétére, melyek támogathatják az átmenettel való megküzdést és hosszú távon megalapozzák a személyiség pszichés ellenállóképességének fejlődését.

\section{A családi tényezők hatása - párkapcsolati elégedettség és konfliktusok}

A szülök közötti kapcsolat minősége és a kapcsolattal való elégedettség mértéke kiemelt közvetítő szerepet tölt be, amikor a családi háttérváltozók hatását vizsgáljuk a gyermeki fejlődéssel összefüggésben. Amikor önmagában a párkapcsolati elégedettségre kérdezünk rá önbeszámolós kérdőívben, gyakran más, a családot érő stresszor hatását vagy az egyén személyiségét tükröző válaszokat kapunk (például depressziós állapotban az egyének negatívabban látják a kapcsolataikat). Ennek a mérése mégis fontos mérőszáma lehet annak, hogy a párkapcsolat mennyire elégíti ki a partnerek érzelmi, szexuális igényeit, menynyire biztosít stabil hátteret. Emellett azonban többen (például Katz and Gottman, 1993) rámutatnak arra, hogy a kapcsolati konfliktusok gyakorisága és megoldási módja jobb viselkedéses mutatója annak, hogy milyen érzelmi légkör jellemző a szülőpárra.

Azok a szülők, akik támogatónak és örömtelinek élik meg a partnerükkel folytatott kapcsolatot, érzelmileg jobban elérhetők gyermekeik számára, és válaszkészebbek a gyermek érzelmi igényeivel szemben (Erel and Burman, 1995). A szülők párkapcsolattal való elégedettsége és mentális egészségük egymással kölcsönhatásban járulnak hozzá a gyermek mentális jóllétéhez. Pontosabban a szülők párkapcsolati elégedettsége és házastársi konfliktusa közvetítő a szülő mentális egészsége (például depresszió várandósság alatt vagy a gyermek születését követően) és a gyermek kimeneti változói között például viselkedéses és érzelmi zavarok esetében (ALSPAC; Hanington et al., 2011), miközben a 
párkapcsolati konfliktusok gyakorisága emeli a gyermek viselkedéses, érzelmi és kognitív problémáinak valószínúségét (Cummings and Davies, 1994). Másrészt a tartós, destruktív szülői konfliktusok közvetlenül veszélyeztetik a gyermek érzelmi biztonságérzetét, minek következtében hatással lehetnek a gyermek pszichés jóllététre (Cummings and Davies, 2002). Mivel feltehetően a szülők közti mindennapi viselkedés az, ami közvetlenül megtapasztalható a gyermek számára, így nem véletlen, hogy ez mutatja a legszorosabb kapcsolatot a gyermek mentális jóllétével és viselkedéses problémáival. Azokban a családokban, ahol a nézeteltéréseket nyílt, de nem túl heves negatív affektusok kíséretében élik meg és rendezik, a partnerek boldogabbnak érzik magukat, és ez megfelelőbb gondozói hátteret nyújt. Ugyanakkor az inadaptív konfliktusmegoldási módok kapcsolatot mutatnak a gyermekek későbbi életkorában tetten érhető viselkedéses zavaraival. Például a szülők közti ellenségesség együtt jár a gyermek három évvel később mutatott agresszív, diszruptív viselkedésével (Davies et al., 2016).

\section{Az anyai pszichés egészség hatása}

A longitudinális kutatások jelentős része foglalkozik azzal a kérdéssel, hogy milyen hatással van az anya pszichés egészségi állapota a gyermek hosszú távú fejlődésére. Stresszel összefüggő pszichés problémák a várandósság alatt vagy a szülést követően nagyon gyakoriak (az anyák 25\%-nál fordul elő), és leggyakrabban depresszió és szorongás formájában manifesztálódnak (Kingston et al., 2012). Az anyai prenatális és posztpartum pszichés egészségromlás közvetlen következményei jól ismertek, növelik az újszülött és csecsemőkori egészségügyi problémák kockázatát (Hobel et al,. 2008). A mentális egészség zavarai (szorongás, depresszió) még abban az esetben is, ha a tünetek súlyossága nem éri el a klinikai diagnózishoz elégséges szintet, komolyan ronthatják a szülői funkcionálást (Korten and Henderson, 2000). A fokozott pszichológia distressz befolyásolja, hogy a szülő mennyire hatékonyan látja el feladatait és milyen mértékben képes érzelmileg elérhető, válaszkész módon reagálni gyermekére. Mindez pedig hozzájárul ahhoz, hogy a gyermek miként teljesíti a fejlődési kihívásokat, mutat-e problémákat a kognitív és társas-érzelmi fejlődés területén. Ennek következtében az anyai pszichés zavarok intenzitása szervesen kapcsolódik a gyermekek érzelmi jóllétéhez, társas kapcsolati nehézségeihez és kognitív készségeik fejlettségéhez (Marryat and Martin, 2010, Prady et al., 2016). Ezt az összefüggést 
támasztotta alá az ALSPAC születési kohorszvizsgálat eredménye is, mely szerint a kisgyermekkori érzelmi-viselkedéses problémák 10-15\%-át az anyai depresszió és szorongás magyarázza (Glover, 2014). További hosszmetszeti vizsgálatok eredményei rámutattak, hogy a krónikus posztpartum depresszióval együtt élő anyák gyermekeinél gyakoribb az érzelmi-viselkedéses nehézségek előfordulása gyermekkorban (Giallo et al., 2015). A depresszió mellett a várandósság idején és a szülést követően fellépő anyai krónikus szorongás befolyásolhatja a magzat és a kisgyermek fejlődését (Monk et al., 2012), megnövekszik a valószínűsége a sérülékenyebb pszichés müködésnek és a gyermekkori viselkedéses problémák megjelenésének.

Az anyai pszichés nehézségek a gyermek társas-érzelmi fejlődése mellett kognitív kompetenciája alakulására is hatással vannak (Gale et al., 2012). Több nagyobb utánkövetéses módszertant alkalmazó vizsgálat bizonyította, hogy az anyák a prenatális, illetve a posztnatális időszakban átélt, klinikai mértéket elérő lelki eredetű problémái (depresszió, szorongás) összefüggenek gyermekük fejlődési lemaradásával és gyengébb kognitív teljesítményével (Cornish et al., 2005, Brouwers et al., 2001). Ezzel együtt az anyák pszichés tünetei és a kognitív fejlődés közötti közvetlen kapcsolatot tanulmányozó vizsgálatok eredményei több ellentmondásra is rámutatnak. Az anyai distressz állapot nem minden esetben jár együtt kedvezőtlen kognitív fejlődési kimenettel (DiPietro et al., 2006). Például nem találtak kapcsolatot az anya posztpartum depressziója és a gyermek kognitív kompetenciáinak fejlettsége között (Sutter-Dallay et al., 2011). Az ilyen ellentmondásos eredmények felvetik azt a lehetőséget, hogy az elemzések nem veszik figyelembe az olyan protektív tényezőket, amelyek moderálják a hatást és a kognitív fejlődést pozitív irányba terelik (Kingston et al., 2015). Másrészt megfontolandó az a felvetés, hogy az anyai distressz és a kognitív fejlődés közötti kapcsolat bár létezik, ugyanakkor nem lineáris (DiPietro et al., 2006). A várandósság alatti és a szülést követő időszakban megélt enyhe fokú szorongás támogatja a gyermek idegrendszeri fejlődését, összehasonlítva a szorongás teljes hiányával, illetve extrém magas szintjével.

A kognitiv fejlődést befolyásoló anyai hatásokat illetően még számos nyitott kérdés vár megválaszolásra. A hosszmetszeti kohorszvizsgálatok segithetnek megérteni, hogy az anyai pszichés problémák mértéke és időbeli paraméterei (például a várandósság mely időszakában áll fenn a depresszió vagy a szorongás) mutatnak-e specifikus hatást a kognitív fejlődés különböző területeire. Másrészt nyitott kérdés, hogy ezek az anyai pszichés hatások milyen közvetítő mechanizmusokon keresztül befolyásolják a gyermek megismerő funkcióinak alakulását. 


\section{A szülő és a gyermek közötti kapcsolat hatása}

A születési kohorszvizsgálatok a családi, a párkapcsolati és az anyai jellemzők vizsgálatán túlmenően célul tủzték ki a gondozó-gyermek közötti kapcsolat megismerését is (összefoglaló tanulmány Belsky and Jaffee, 2015). A gondozó-gyermek közötti kapcsolat sajátosságait számtalan megközelítésből vizsgálhatjuk a gyermek életkorától függően. Csecsemőkorban többnyire a válaszkészséget, a törődés és az elhanyagolás vagy a rossz bánásmód hatását kutatják, kisgyermekkorban az anyai melegség és hosztilitás a kérdés; későbbi gyermekkorban a gyermeki viselkedés szülői kontrollja, a nevelési attitűdök és a tevékenységekbe (például iskolai aktivitásba) való bevonódás mértéke kerül középpontba; serdülőkorban az autonómia támogatása számít kiemelt változónak. A szakirodalom általában pozitív és negatív szülői stratégiákról beszél, annak fényében, hogy alkalmazásuk jobb vagy rosszabb prognózisú fejlődési kimenetekhez vezet-e (Rajyaguru et al., 2019). Pozitív szülői gondozás alatt érzékeny, válaszkész és érzelmileg meleg viszonyulást értenek, amelynek az adaptív fejlődésben betöltött szerepe empirikusan alátámasztott (Bornstein and Manian, 2013). A negatív szülői gondozás rendszerint szigorú, büntető viszonyulást, ellenséges érzéseket és fokozott pszichológiai kontrollt, a gyermek érzelmi autonómiájának korlátozását foglalja magában (Morris et al., 2002).

A szülői kontroll, a gyermeki viselkedés szabályozása klasszikus téma a fejlődéslélektanban, hiszen az optimális fejlődéshez a szülőnek jól kommunikált, következetes és biztonságot nyújtó kereteket kell teremtenie és fenntartania. A kontroll átfogó fogalmát Barber (1996) javaslatát követve fel szokták osztani pszichológiai és viselkedéses kontrollra. Ennek hátterében az áll, hogy a kétféle kontroll más módon jelenik meg a szülői viselkedésben, és túlzó alkalmazásuk eltérő fejlődési utakhoz vezet. Pszichológiai kontroll alatt rendszerint olyan, a gyermek pszichológiai és érzelmi folyamataiba túlzóan beavatkozó szülői viselkedéseket értenek, mint a gyermek lekicsinyléssel, érzelmeinek vagy szándékainak érvénytelenítésével, szeretetmegvonással és bűntudat vagy szégyen keltésével való korlátozása. A kohorszkutatásokban a túlzottan intruzív, szeretetmegvonásos büntetéssel vagy érzelmi manipulációval élő szülői viselkedés sorolható a pszichológiai kontroll fogalomkörébe. A viselkedéses kontroll mindezzel szemben a szülői ellenőrzésre, felügyeletre és a következetesen elvárt és betartott/betartatott viselkedési korlátokra vonatkozik. Míg a pszichológiai kontroll túlzott alkalmazása a személyes hatékonyság és a pozitiv énkép fenyegetése mentén a mentális problémák előfordulásával jár együtt, addig a viselkedéses kontroll a szelfszabályozás támogatásán keresz- 
tül csökkenti a diszruptív, antiszociális viselkedési problémák előfordulását (Barber et al., 2005).

A kohorszvizsgálatok módot adnak arra, hogy a szülői fegyelmezési módok hosszú távú hatásait és az azokra ható tágabb környezeti tényezőket felfedjük. A család szocioökonómiai háttere jól bizonyított kapcsolatot mutat a szülői fegyelmezési és kontrollviselkedésekkel (Hoff et al., 2002). Az alacsonyabb SES családokban például több a közvetlenül a viselkedés irányítására vonatkozó verbális interakció az anya és a gyermek között (Hoff-Ginsberg, 1998), valamint gyakoribb a fizikai büntetés is (Straus and Stewart, 1999). A születési kohorszvizsgálatok ezeket az evidenciákat képesek megerősíteni vagy cáfolni robosztus mintákon. Jones (2010) és a Kiernan-Huerta szerzőpáros (2008) az előbbiekben felvázolt mintázatot találták az MCS-ben angol családoknál: a fizikai büntetés, a manipulatív irányítás, a gyermek fizikai korlátozásának és megbélyegzésének gyakorisága, tehát a fokozottab pszichológiai és viselkedéses kontroll megjelenése egyaránt fordított arányban áll a család szegénységével és gazdasági depriváltságával.

A negatív fegyelmezési stratégiák hosszú távú hatásairól több kohorszalapú kutatásból tájékozódhatunk. Egy az MCS adataira alapozó kutatás (Rajyaguru et al., 2019) a kora gyermekkori aktív (fizikai büntetés, szidás) és szeretetmegvonásra építő (kizárás, beígért jutalom megvonása, figyelmen kívül hagyás) fegyelmezési módok viselkedéses problémákra kifejtett jelen idejü és prospektív hatását vizsgálta. Az eredmények alapján arra következtethetünk, hogy az aktív büntetés egyik oldalról csökkenti a magatartásproblémák előfordulásának gyakoriságát, másik oldalról viszont növeli az érzelmi problémák előfordulását és csökkenti a proszociális viselkedés előfordulásának esélyét. Egy másik, az LSAC adatait elemző vizsgálat (Bayer et al., 2011) szintén a gyermekkori mentális egészségre ható rizikó-, illetve protektív tényezőként vizsgálta az egyes szülői viszonyulási módokat és viselkedéseket a gyerekek 1-9 éves kora közötti intervallumban. A durva fizikai büntetés, a túlvédő (intruzív) anyai viselkedés és a szülői érvelő és következetes fegyelmezés hosszú távú hatásait vették górcső alá. Összességében a szülői nevelési, viszonyulási módok közül a durva fizikai büntetés minden életkori hullámban jelentős erővel jelezte előre a gyermekkori magatartási és érzelmi zavarok előfordulását, míg a túlvédő (intruzív) anyai viszonyulási mód az érzelmi zavarokkal mutatott kapcsolatot, de csak kora gyermekkorban. Ezek az eredmények azt ígérik, hogy pontosabban tudjuk azonositani a gyermekkori mentális zavarok kialakulására ható szülői viszonyulásokat. Ugyanakkor nem szabad figyelmen kívül hagyni, föleg a keresztmetszeti elemzéseknél, hogy a gyermek viselkedési vagy érzelmi problémája alakítja a szülő viszonyulását 
is (például egy szorongó, lehangolt gyermek túlvédő viselkedést vált ki a gondozóból), így az oksági következtetéseket megfontoltan érdemes átgondolni.

A gondozó gyermek iránti érzelmi elköteleződése már a várandósság idején bontakozni kezd azzal, ahogy bevonódik a magzattal való kommunikációba, a gyermek személyiségének és jövőjének elképzelésébe. Ezt a jelenséget az anya magzat iránti kötődésének (Condon, 1993) nevezzük, és összefoglaló tanulmányok sora mutat rá, hogy minősége kapcsolatban áll a korai fejlődéssel (Branjerdporn et al., 2017) és a gondozó-gyermek közti kapcsolat születés utáni alakulásával (Müller, 1996). Ugyanakkor a nagy volumenű születési kohorszvizsgálatok ritkán alkalmaznak prenatális adatfelvételi hullámot, és ebbe még ritkábban vonják be az anya magzat iránti kötődésének változóját. Így inkább kisebb volumenű és rövidebb időtávot átfogó prospektív longitudinális kutatások igazolják a feltételezett pozitív kapcsolatot az anya-magzat kötődés és a születés utáni anyai kötődés között (például Rossen et al., 2016).

A csecsemőkori gondozó-gyermek kapcsolat minőségének hosszú távú hatásaiba azonban már több kohorszvizsgálat betekintést ad, és a szülő-gyerek kapcsolat jellemzőiről is mint az adaptív fejlődést előmozdító vagy hátráltató tényezőkről gondolkodnak. Az ausztrál vizsgálatra (LSAC) épülő egyik kutatásban (Zimmer-Gembeck and Thomas, 2010) a csecsemőkori anyai melegség és hosztilitás mutatott kapcsolatot a kisgyermekkori társas-érzelmi kompetenciákkal és viselkedéses problémákkal: a hosztilitás elsősorban a viselkedéses problémák esélyét növelte, a melegség pedig a társas problémák megjelenésének előfordulását csökkentette. A vizsgálatban az anyai melegség és hosztilitás az anyai pszichés állapot és a gyermek alkalmazkodási képessége közti közvetítő tényezőként volt jelen (anyai depresszió > hosztilitás > gyermeki viselkedési problémák; anyai én-hatékonyság > melegség > kevesebb társas probléma). Így ezek az eredmények arra is rávilágítanak, hogy az anyai mentális állapot mint személyes jellemző összefonódik az anya-gyerek kapcsolat minőségével és a párkapcsolati müködések hatásaival. Egy másik, az LSAC adatokra épülő tanulmány (Cooklin et al., 2013) az adaptív fejlődést hátráltató anyai viszonyulási mód (a gyermek csecsemőkorában mutatott fokozott anyai szeparációs szorongás) és a 2-3 éves korban mért társas és érzelmi problémák kapcsolatát tudta kimutatni úgy, hogy mediáló tényezőként a kisgyerekkori túlvédő, korlátozó szülői viszonyulást azonosították. Fejlődéslélektani nézőpontból ez az eredmény azért is informatív, mert egy csecsemőkori és egy kisgyerekkori maladaptív anyai viszonyulási mód feltételezett folytonosságát erősíti meg.

A kutatások másik része - kihasználva a kohorszvizsgálatok széles körü környezeti változókhoz való hozzáférésének lehetőségét - arra keresi a választ, 
hogy a pozitív szülői gondoskodás mint védőfaktor hogyan lép interakcióba az adaptív fejlődést veszélyeztető vagy hátráltató társas-társadalmi tényezőkkel. A brit MCS adatait elmezve Flouri és munkatársai (2015) azt találták, hogy a szülő-gyermek közti érzelmi melegség és a szülő gyermeki tevékenységekbe való bevonódása bizonyos mértékig képes moderálni a szocioökonómiai hátrányok és a negatív életesemények viselkedéses problémákat növelő hatását. A szülői melegség és válaszkészség tehát valószínűleg a rizikótényezőkkel szembeni érzelmi és viselkedéses rezilienciához járul hozzá. Mindeközben újabb eredmények rámutatnak, hogy a pozitív szülői gondoskodás (melegség, bevonódás) nem mindig váltja ki az elvárt hatást, például sokszor nem tudja ellensúlyozni a társadalmi hátrányok negatív következményét. Például az MCS adatait elemezve Hartas (2015) azt találta, hogy a szülői melegség, a szülői fegyelmezési mód és az otthoni tanulási környezet nem járul hozzá annak előrejelzéséhez, hogy milyen a gyerekek első osztály végén mutatott iskolai eredménye. A korai iskolai eredményeket jóval erősebben jelzik előre a család jövedelmi viszonyai és az anya iskolai végzettsége, mint a szülők otthoni aktivitása és a gyermekhez való érzelmi viszonyulása.

\section{ÖSSZEFOGLALÁS}

A születési kohorszvizsgálatok olyan magas ökológiai validitású fejlődési modelleket alapoznak meg, amelyek segítségével megismerhetjük, miként bontakozik ki és hogyan változik a gyermek veleszületett adottsága az életkörülmények, a családi és a társas kapcsolatok együttes hatására. A gyermek várható fejlődési kimenetét egyéni jellemzői, a szülői tényezők, a szülők közötti kapcsolat, a gyermek és az anya közötti kapcsolat minősége, valamint a gyermek és családja mikrokörnyezeti és makrokörnyezeti jellemzői együttesen határozzák meg. E tényezők közül a rizikófaktorok jelenléte és halmozódása növeli az esélyét annak, hogy a gyermek kognitív, társas és érzelmi kompetenciái elmaradnak az átlagosan elvárhatótól. A védőfaktorként funkcionáló jellemzők ugyanakkor képesek módosítani vagy megakadályozni, hogy a nehéz szociális és/vagy környezeti tényezők hatására a gyermek felnövekedése maladaptív irányba fejlődjön. Célunk szerint tanulmányunkban bemutattuk azt a gondolkodási keretet, amelyben a fejlődést befolyásoló tényezők egymásra hatásának útjai vizsgálhatók, leírhatók és értelmezhetők, és sikerült láttatni a kurrens vizsgálatok főbb eredményeit egy-egy kiemelt változón keresztül. 
Ugyanakkor rá kell mutatnunk, hogy munkánk nyilvánvaló korlátja a pszichológiai kérdések áttekintésének részlegessége. A megvizsgált területek kiválasztásában saját érdeklődési körünk és a Kohorsz'18 Magyar Születési Kohorszvizsgálat tervezése során felmerült kérdések és megoldások vezették a gondolkodásunkat. A tanulmány másik korlátozó körülménye a pszichológiai változók és a fejlődést bármely irányba módosító tényezők lineáris sorba rendezése és bonyolult kapcsolatuk leírása, hiszen ahogy többször is utaltunk rá, ezek a tényezők egymással folyamatos kölcsönhatásban állnak, és egymás moderáló, mediáló tényezőiként is müködnek. Így képezik le a fejlődés kontextusát adó kölcsönhatások bonyolult rendszerét, amiből a kutatások mindig csak egy-egy pillanatképet tudnak megragadni. 


\section{IRODALOM}

Agnafors, S., Svedin, C. G., Oreland, L., Bladh, M., Comasco, E. and Sydsjö, G. (2017). Biopsychosocial approach to risk and resilience on behavior in children followed from birth to age 12. Child Psychiatry and Human Development, 48(4), 584-596.

Barber, B K. (1996). Parental psychological control: Revisiting a neglected construct. Child Development, 67(6), 3296-3319.

Barber, B. K., Stolz, H. E., Olsen, J. A., Collins, W. A. and Burchinal, M. (2005). Parental support, psychological control, and behavioral control: Assessing relevance across time, culture, and method. Monographs of the Society for Research in Child Development, 70(4), 1-147.

Bass L. (2007). Az esélyegyenlőtlenségek dinamikája. A Budapesti Longitudinális Fejlődésvizsgálat eredményei a gyermekek szocializációjának társadalmi meghatározottságáról. Gyerekesély Füzetek 2. Budapest: MTA GYEP.

Bayer, J. K., Ukoumunne, O. C., Lucas, N, Wake, M., Scalzo, K. and Nicholson, J. M. (2011). Risk factors for childhood mental health symptoms: national longitudinal study of Australian children. Pediatrics, 128(4), e865-e879.

Belsky, J. and Jaffee, S. R. (2015). The multiple determinants of parenting. In D. Cicchetti, D. J. Cohen and J. Donald (Eds.), Developmental psychopathology 2nd edition, Volume three. Risk, disorder, and adaptation (pp. 38-85). New Jersey: John Wiley \& Sons Inc.

Blair, C., Raver, C. C., Granger, D., Mills-Koonce, R., Hibel, L., \& Family Life Project Key Investigators (2011). Allostasis and allostatic load in the context of poverty in early childhood. Development and psychopathology, 23(3), 845-857.

Blair, C. and Raver, C. C. (2016). Poverty, stress, and brain development: New directions for prevention and intervention. Academic Pediatrics, 16(3), S30 - S36.

Blaskó Zs. (2009). Születési kohorsz-vizsgálatok itthon és külföldön - tapasztalatok és tanulságok. Esély, (6), 45-75.

Bornstein, M. H. and Manian, N. (2013). Maternal responsiveness and sensitivity reconsidered: Some is more. Development and Psychopathology, 25(4), 957-971.

Branjerdporn, G., Meredith, P., Strong, J. and Garcia, J. (2017). Associations between maternal-foetal attachment and infant developmental outcomes: A systematic review. Maternal and Child Health Journal, 21(3), 540 - 553.

Bronfenbrenner, U. and Ceci, S. J. (1994). Nature-nurture reconceptualized in developmental perspectives: A bioecological model. Psychological Review, 101, 568-586.

Brouwers, E. P. M., van Baar, A. L. and Pop, V. J. M. (2001). Maternal anxiety during pregnancy and subsequent infant development. Infant Behavior and Development, 24(1), 95-106.

Brown, S. L., Stykes, J. B. and Manning, W. D. (2016). Trends in children's family instability, 1995-2010. Journal of Marriage and Family, 78(5), 1173-1183.

Bzostek, S. H. and Beck, A. N. (2011). Familial instability and young children's physical health. Social Science \& Medicine, 73(2), 282-292.

Coley, R. L., Votruba-Drzal, E., Miller, P. L. and Koury, A. S. (2013). Timing, extent, and type of child care and children's behavioral functioning in kindergarten. Developmental Psychology, 49(10), 1859-1873. 
Coley, R. L., Lombardi, C. M., and Sims, J. (2015). Long-term implications of early education and care programs for Australian children. Journal of Educational Psychology, 107(1), 284-299.

Coley, R. L., Votruba-Drzal, E., Collins, M. and Cook, K. D. (2016). Comparing public, private, and informal preschool programs in a national sample of low-income children. Early Childhood Research Quarterly, 36, 91-105.

Condon, J. T. (1993). The assessment of antenatal emotional attachment: Development of a questionnaire instrument. British Journal of Medical Psychology, 66(2), 167-183.

Cooklin, A. R., Giallo, R., D’Esposito, F., Crawford, S. and Nicholson, J. M. (2013). Postpartum maternal separation anxiety, overprotective parenting, and children's social-emotional well-being: Longitudinal evidence from an Australian cohort. Journal of Family Psychology, 27(4), 618-628.

Cornish, A. M., McMahon, C. A., Ungerer, J. A., Barnett B., Kowalenko, N. and Tennant, C. (2005). Postnatal depression and infant cognitive and motor development in the second postnatal year: The impact of depression chronicity and infant gender. Infant Behavior and Development, 28(4), 407-417.

Cummings, E. M. and Davies, P. (1994). Children and marital conflict: The impact of family dispute and resolution. New York: Guilford.

Cummings, E. M. and Davies, P. (2002). Effects of marital conflict on children: recent advances and emerging themes in process oriented research. Journal of Child Psycho/ogy and Psychiatry, 43(1), 31-63.

Danis I. és Kalmár M. (2011). A fejlődés természete és modelljei. In Danis I., Farkas M., Herczog M. és Szilvási L. (szerk.), A génektől a társadalomig: a kora gyermekkori fejlődés szinterei (74-122. o.). Budapest: Nemzeti Család- és Szociálpolitikai Intézet.

Davies, P., Hentges, R. F., Coe, J. L., Martin, M. J., Sturge-Apple, M. L. and Cummings, E. M. (2016). The multiple faces of interparental conflict: Implications for cascades of children's insecurity and externalizing problems. Journal of Abnormal Psychology, 125(5), 664-678.

DiPietro, J. A., Novak, M. S. F. X., Costigan, K. A., Atella, L. D. and Reusing, S. P. (2006). Maternal psychological distress during pregnancy in relation to child development at age two. Child Development, 77(3), 573-587.

Douglas, J. W. B., Ross, J. M., and Simpson, H. R. (1968). All our future. London: Peter Davies Ltd.

Dowsett, C. J., Huston, A. C., Imes, A. E. and Gennetian, L. (2008). Structural and process features in three types of child care for children from high and low income families. Early Childhood Research Quarterly, 23(1), 69-93.

DuMont, K. A., Widom, C. S. and Czaja, S. J. (2007). Predictors of resilience in abused and neglected children grown-up: The role of individual and neighborhood characteristics. Child Abuse and Neglect, 31(3), 255-274.

Erel, O. and Burman, B. (1995). Interrelatedness of marital relations and parent-child relations: A meta-analytic review. Psychological Bulletin, 118(1), 108-132.

Evans, G. W., Li, D., and Whipple, S. S. (2013). Cumulative risk and child development. Psychological Bulletin, 139(6), 1342-1396. 
Flouri, E., Midouhas, E., Joshi, H. and Tzavidis, N. (2015). Emotional and behavioural resilience to multiple risk exposure in early life: The role of parenting. European Child amd Adolescent Psychiatry, 24(7), 745-755.

Fomby, P. and Cherlin, A. J. (2007). Family instability and child well-being. American Sociological Review, 72(2), 181-204.

Fomby, P. (2011). Family instability and school readiness in the United Kingdom. Family Science, 2(3), 171-185.

Gale, C. R., Cooper, R., Craig, L., Elliott, J., Kuh, D., Richards, M., Starr, J. M., Whalley, L. J. and Deary, I. J. (2012). Cognitive function in childhood and life-time cognitive change in relation to mental wellbeing in four cohorts of older people. PLoS One, 7(9), e44860.

Gárdos É. (1990). Terhesek és csecsemők egészségügyi és demográfiai vizsgálata. Budapest: KSH.

George, L. (1993). Sociological perspectives on life transitions. Annual Review of Sociology, 19(1) 353-373.

Gerard, J. M. and Buehler, C. (2004). Cumulative environmental risk and youth maladjustment: the role of youth attributes. Child Development, 75(6), 1832-1849.

Gervai J. (2005). A Budapesti Családvizsgálat. Alkalmazott Pszichológia, 7(4), 5-13.

Giallo, R., Woolhouse, H., Gartland, D., Hiscock, H. and Brown, S. )2015). The emotionalbehavioural functioning of children exposed to maternal depressive symptoms across pregnancy and early childhood: a prospective Australian pregnancy cohort study. European Child \& Adolescent Psychiatry, 24(10), 1233-1244.

Glover, V. (2014). Maternal depression, anxiety and stress during pregnancy and child outcome; what needs to be done. Best Practice \& Research Clinical Obstetrics \& Gynaecology, 28(1), 25-35.

Hadfield, K., Amos, M., Ungar, M., Gosselin, J. and Ganong, L. (2018). Do changes to family structure affect child and family outcomes? A systematic review of the instability hypothesis. Journal of Family Theory and Review, 10(1), 87-110.

Hanington, L., Heron, J., Stein, A. and Ramchandani, P. (2011). Parental depression and child outcomes - Is marital conflict the missing link? Child: Care, Health and Development, 38(4), 520-529.

Hartas, D. (2015). Parenting for social mobility? Home learning, parental warmth, class and educational outcomes. Journal of Education Policy, 30(1), 21-38.

Hobel, C. J., Goldstein, A. and Barrett, E. S. (2008). Psychosocial stress and pregnancy outcome. Clinical Obstetrics and Gynecology, 51(2), 333-348.

Hoff, E., Laursen, B. and Tardif, T (2002). Socioeconomic status and parenting. In M. H. Bornstein and H. Marc H. (Eds.), Handbook of parenting (Vol. 2) (pp. 231-252). Mahwah-London: Lawrence Erlbaum Associates.

Hoff-Ginsberg, E. (1998). The relation of birth order and socioeconomic status to children's language experience and language development. Applied Psycholinguistics, 19(4), 603-629.

Jones, E. (2010) Parental relationships and parenting. In K. Hansen, H. Joshi and S. Dex (Eds.), Children of the 21st century (Volume 2), the first five years (pp. 53-73). Bristol: Policy Press. 
Joubert K. és Gárdos É. (1991). Terhesek és csecsemők egészségügyi és demográfiai vizsgálata. A Központi Statisztikai Hivatal Népességtudományi Kutató Intézetének kutatási jelentései 40. Budapest: KSH Népességtudományi Kutatóintézet.

Joubert K. (szerk.) (2006). Az országos longitudinális gyermeknövekedés-vizsgálat eredményei születéstől 18 éves korig I. A Központi Statisztikai Hivatal Népességtudományi Kutató Intézetének kutatási jelentései 83. Budapest: KSH Népességtudományi Kutatóintézet.

Kalil, A. and Ryan, R. M. (2010). Mothers' economic conditions and sources of support in fragile families. The Future of Children, 20(2), 39-61.

Katz, L. F. and Gottman, J. M. (1993). Patterns of marital conflict predict children's internalizing and externalizing behaviors. Developmental Psychology, 29(6), 940.

Khambati, N., Mahedy, L., Heron, J. and Emond, A. (2018). Educational and emotional health outcomes in adolescence following maltreatment in early childhood: A population-based study of protective factors. Child Abuse \& Neglect, 81, 343-353.

Kiernan, K. E. and Huerta, M. C. (2008). Economic deprivation, maternal depression, parenting and children's cognitive and emotional development in early childhood. British Journal of Sociology, 59(4), 783-806.

Kingston, D., Heaman, M., Fell, D., Dzakpasu, S. and Chalmers, B. (2012). Factors associated with perceived stress and stressful life events in pregnant women: findings from the Canadian Maternity Experiences Survey. Maternal and Child Health Journal, 16(1), 158-168.

Kingston, D., McDonald, S., Austin, M.-P. and Tou, S. (2015). Association between prenatal and postnatal psychological distress and toddler cognitive development: A systematic review. PloS one, 10(5), e0126929.

Korten, A. and Henderson, S. (2000). The Australian National Survey of Mental Health and Well-Being: Common psychological symptoms and disablement. The British Journal of Psychiatry, 177(4), 325-330.

Lacey, R. E., Bartley, M., Pikhart, H., Stafford, M. and Cable, N. (2014). Parental separation and adult psychological distress: an investigation of material and relational mechanisms, BMC Public Health, 14(1), 272- 282.

Lee, D. and McLanahan, S. (2015). Family structure transitions and child development: Instability, selection, and population heterogeneity. American Sociological Review, 80(4), 738-763.

Luthar, S. S. and Zelazo, L. B. (2003). Research on resilience: An integrative review. In S. S. Luthar (Ed.), Resilience and vulnerability: Adaptation in the context of childhood adversities (pp. 510- 549). New York: Cambridge University Press,

Marryat, L. and Martin, C. (2010). Growing up in Scotland: Maternal mental health and its impact on child behaviour and development. Project report. Edinburgh: Scottish Government.

Masten, A. S. (2007). Resilience in developing systems: progress and promise as the fourth wave rises. Development and Psychopathology, 19(03), 921-930.

McLanahan, S. and Sandefur, G. (1994). Growing up with a single parent: What hurts, what helps. Cambridge: Harvard University Press. 
Meng, X., Fleury, M.-J., Xiang, Y.-T., Li, M. and D’Arcy, C. (2018). Resilience and protective factors among people with a history of child maltreatment: a systematic review. Social Psychiatry and Psychiatric Epidemiology, 53(5), 453-475.

Monk, C., Spicer, J. and Champagne, F. A. (2012). Linking prenatal maternal adversity to developmental outcomes in infants: the role of epigenetic pathways. Development and Psychopathology, 24(4), 1361-1376.

Morris, A., Silk, J. S., Steinberg, L., Sessa, F. M., Avenevoli, S. and Essex, M. J. (2002). Temperamental vulnerability and negative parenting as interacting predictors of child adjustment. Journal of Marriage and Family, 64(2), 461-471.

Morton, S. M. B., Atatoa Carr, P. E., Grant, C. C., Berry, S. D., Marks, E. J., Chen, X. M-H., and Lee, A. C. (2014) Growing up in New Zealand: A longitudinal study of New Zealand children and their families. Vulnerability report 1: Exploring the definition of vulnerability for children in their first 1000 days. Auckland: Growing Up in New Zealand.

Morton, S. M. B., Atatoa Carr, P. E., Grant, C. C., Berry, S. D. D., Mohal, J. and Pillai, A. (2015). Growing up in New Zealand: A longitudinal study of New Zealand children and their families. Vulnerability report 2: Transitions in exposure to vulnerability in the first 1000 days of life. Auckland: Growing Up in New Zealand.

Müller, M. E. (1996). Prenatal and postnatal attachment: a modest correlation. Journal of Obstetric, Gynecologic, \& Neonatal Nursing, 25(2), 161-166.

Osborne, C. and McLanahan, S. (2007) Partnership instability and child well-being. Journal of Marriage and Family, 69(4), 1065-1083.

Prady, S. L.,Pickett, K. E., Croudace, T., Mason, D., Petherick, E. S., McEachan, R. R. C., Gilbody, S. and Wright, J. (2016). Maternal psychological distress in primary care and association with child behavioural outcomes at age three. Eurpean Child Adolescense Psychiatry, 25(6), 601-613.

Rajyaguru, P., Moran, P., Cordero Vega, M. and Pearson, R. M. (2019). Disciplinary parenting practice and child mental health: evidence from the UK Millennium Cohort Study. Journal of the American Society of Child and Adolescent Psychiatry, 55(10), S200-S201.

Ranschburg J. és Horváth I. (1985). Az anyai magatartás (a „szoptatás” és az „egyedül hagyás") szocio-kulturális és pszichológiai feltételei. Pszichológia, 5(4), 565-577.

Ranschburg J., Cseh K. és Sipos M. (1995). A csecsemőkori intelligencia kapcsolata a szociális környezeti hatásokkal és a szülői intelligenciával. Pszichológia, 15(1), 43-59.

Rossen, L., Hutchinson, D., Wilson, J., Burns, L., Olsson, C. A., Allsop, S., Eliott, E. J., Jacobs, S., Macdonald, J. A. and Mattick, R. P. (2016). Predictors of postnatal mother-infant bonding: the role of antenatal bonding, maternal substance use and mental health. Archives of Women's Mental Health, 19(4), 609-622.

Rutter, M. (1989). Isle of Wight revisited: Twenty-five years of child psychiatric epidemiology. Journal of the American Academy of Child and Adolescent Psychiatry, 28(5), 633-653.

Rutter, M., Dunn, J., Plomin, R., Simonoff, E., Pickles, A., Maughan, B., Ormel, J., Meyer, J. and Eaves, L. (1997). Integrating nature and nurture: Implications of person - environment correlations and interactions for developmental psychopathology. Development and Psychopathology, 9(2), 335-366. 
Sameroff, A. and Chandler, M. (1975). Reproductive risk and the continuum of caretaking casualty. In F. D. Horowitz, M. Hetherington, S. Scarr-Salapatek and G. Siegal (Eds.), Review of Child Development Research (Vol. 4) (pp. 187-244). Chicago: University of Chicago Press.

Sameroff, A. J., and Seifer, R. (1983). Familial risk and child competence. Child Development, 54(5), 1254-1268.

Sameroff, A. J., Seifer, R., Zax, M. and Barocas, R. (1987). Early indicators of developmental risk: The Rochester Longitudinal Study. Schizophrenia Bulletin, 13(3), 383-393.

Schoon, I., Bynner, J., Joshi, H., Parsons, S., Wiggins, R. D. and Sacker, A. (2002). The influence of context, timing, and duration of risk experiences for the passage from childhood to midadulthood. Child Development, 73(5), 1486-1504.

Straus, M. A. and Stewart, J. H. (1999). Corporal punishment by American parents: National data on prevalence, chronicity, severity, and duration, in relation to child and family characteristics. Child and Family Psychology Review, 2(2) 55-70.

Sun, Y. and Li, Y. (2014). Alternative households, structural changes, and cognitive development of infants and toddlers. Journal of Family Issues, 35, 1440-1472.

Sutter-Dallay, A. L., Murray, L., Dequae-Merchadou, L., Glatigny-Dallay, E., Bourgeois ML, and Verdoux H. (2011). A prospective longitudinal study of the impact of early postnatal vs. chronic maternal depressive symptoms on child development. European Psychiatry, 26(8), 484-489.

Thornton, A. (2004). Introduction and overview. In A. Thornton (Ed.), The well-being of children and families (pp. 3-27). Ann Arbor: The University of Michigan Press.

Ungar, M. (2015). Social ecological complexity and resilience processes. Behavioral and Brain Sciences, 38, e124.

Vermeer, H. J. and van IJzendoom, M. H. (2006). Children's elevated cortisol levels at daycare: A review and meta-analysis. Early Childhood Research Quarterly, 21(3), 390-401.

Veroszta Zs. (szerk.) (2018). Kutatási koncepció. Kohorsz'18 Magyar Születési Kohorszvizsgálat. A Központi Statisztikai Hivatal Népességtudományi Kutató Intézetének kutatási jelentései 100. Budapest: KSH Népességtudományi Kutatóintézet.

Warren, D. (2017). Low-income and poverty dynamics implications for child outcomes. Social Policy Research Paper No 47. Australian Institute of Family Studies.

Zimmer-Gembeck, M. J. and Thomas, R. (2010). Parents, parenting and toddler adaptation: Evidence from a national Iongitudinal study of Australian children. Infant Behavior and Development, 33(4), 518-529. 


\section{ABSTRACT}

In recent decades, beside the more traditional epidemiologically focused birth cohort studies, complex biopsychological - ecological approaches have become increasingly highlighted. Current review has a twofold purpose: on the one hand, we present a complex framework of interpretation in which developmental changes can be interpreted on a multilevel process involving distal and proximal factors. On the other hand, we review psychological research questions and novel results that can be considered in international cohort studies. From a psychological perspective two main research questions have emerged in cohort studies: 1. how adaptive/maladaptive developmental pathways unfold alongside risk- and protective factors, 2 . what direct and indirect effects shape the resilient development. In this paper, we discuss the results of significant national cohort studies emphasizing social and family variables, and the findings of smaller-scale longitudinal studies also complementing their results. 